\title{
Influence of graded levels of cassava peels and palm kernel cake meal on performance of weaner pigs
}

${ }^{1}$ Moseri, H., ${ }^{1}$ Umeri, C. and ${ }^{2}$ Amaza, I. B.

${ }^{1}$ Department of Agricultural Education, College of Education Agbor,

Delta State, Nigeria.

${ }^{2}$ Department of Animal Science, Federal University Gashua, Yobe State, Nigeria

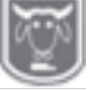

Corresponding author: mosierihillary@gmail.com Phone: 08059138901.

\section{Abstract}

Feeding trial was conducted to evaluate the effects of cassava peels/palm kernel cake meal on the performance and economic benefits of weaner pigs. Fifty (50) large white weaner pigs of mixed sexes with average of $9.80 \pm 0.4 \mathrm{~kg}$ were randomly allocated to the five dietary treatments in a completely randomized design (CRD) with ten pigs per treatment. The experimental diets which consist of mixture of cassava peels and palm kernel cake had ratio of 1:1. The mixture replaced maize at 0 (control), 10, 20, 30 and 40\%. Feed and water were made available as required. The growth and economic indices measured were feed intake, weight gain, feed conversion ratio, protein efficiency ratio, mortality, feed cost (N/kg), total cost offeed consumed per pig(N) live weight gain, revenue per total live weight gain per pig $(N)$, gross profit per pig $(N)$.The results revealed that average weekly weight gain was significantly higher $(P<0.05)$ for weaner pigs fed on control diet with a value of $(2.00 \mathrm{~kg})$ while the least values of $1.71 \mathrm{~kg}$ were recorded for $40 \%$ levels of inclusion. Average final body weight gain values of 24.20, 23.25, 22.60, 22.20 and $21.90 \mathrm{~kg}$ differed significantly $(P<0.05)$ amongst the dietary treatments. Average feed intake was higher $(P<0.05)$ on the control (35.52kg/day) than on diets 10 (33.50), $20(30.64), 30(30.00)$ and $40(30.40 \mathrm{~kg})$ in that order. It was observed that average weekly gain, average final weight gain and average feed intake declined with increasing levels of test ingredients. However, feed conversion ratio was better $(P<0.05)$ for weaner pigs fed on 20\% (2.47) diet than those fed on 0,10, 30, and $40 \%$ which had values of 2.57; 2.49; 2.48 and 2.54) correspondingly. Protein efficiency ratio (PER) was better on $20 \%$ (2.38) compared to $30 \%$ (2.37), 10\% (2.36), while $0 \%$ and $40 \%$ (2.32) had similar values. Pigs fed on 40\% level test ingredient were better economically than other treatments groups. In view of highest return on investment, $40 \%$ combination Cassava/PKC meal is recommended.

Keywords: Weaner pigs, Cassava peels/palm kernel cake, performance, and cost benefit

L'Influence des niveaux gradués de pelures de manioc et d'aliment de 'galette de palmkernel' sur les performances des porcs sevrés

${ }^{1}$ Moseri, H., ${ }^{1}$ Umeri, C. et ${ }^{2}$ Amaza, I. B.

${ }^{I}$ Department of Agricultural Education, College of Education Agbor,

Delta State, Nigeria.

${ }^{2}$ Department of Animal Science, Federal University Gashua, Yobe State, Nigeria

(2)

Corresponding author: mosierihillary@gmail.com Phone: 08059138901.

\section{Résumé}

Un essai d'alimentation a été mené pour évaluer les effets des pelures de manioc $/$ 'palmkernel'sur les performances et les avantages économiques des porcs sevrés. Cinquante (50) gros porcs sevrés blancs de sexes mixtes avec une moyenne de 9,80 \pm 0,4 kg ont été 


\section{Influence of graded levels of cassava peels and palm kernel cake meal on performance of weaner pigs}

attribués au hasard aux cinq traitements diététiques dans une conception complètement randomisée (CRD) avec dix porcs par traitement. Les régimes expérimentaux qui consistent en un mélange de pelures de manioc et de 'palm kernel' avaient un rapport de $1: 1$. Le mélange a remplacé le maïs à 0 (témoin), 10, 20, 30 et 40\%. L'alimentation et l'eau ont été mises à disposition selon les besoins. Les indices de croissance et économiques mesurés étaient la consommation alimentaire, le gain de poids, le taux de conversion alimentaire, le taux d'efficacité protéique, la mortalité, le coût de l'alimentation ( $N / \mathrm{kg})$, le coût total de l'alimentation consommée par porc (N) gain de poids vif, le revenu par poids vif total gain par porc $(N)$, bénéfice brut par porc $(N)$.Les résultats ont révélé que le gain de poids hebdomadaire moyen était significativement plus élevé $(P<0.05)$ pour les porcs sevrés nourris avec un régime témoin avec une valeur de (2,00 kg) tandis que les valeurs les plus faibles de $1,71 \mathrm{~kg}$ ont été enregistrés pour des niveaux d'inclusion de 40\%. Les valeurs de gain de poids corporel finales moyennes de 24,20, 23,25, 22,60, 22,20 et 21,90 kg différaient significativement $(P<0,05)$ parmi les traitements diététiques. La prise alimentaire moyenne était plus élevée $(P<0.05)$ sur le contrôle $(35,52 \mathrm{~kg} / \mathrm{jour})$ que sur les régimes $10(33,50), 20$ $(30,64), 30(30,00)$ et $40(30,40 \mathrm{~kg})$ dans cet ordre. Il a été observé que le gain hebdomadaire moyen, le gain de poids final moyen et la consommation alimentaire moyenne diminuaient avec l'augmentation des niveaux d'ingrédients d'essai. Cependant, le taux de conversion alimentaire était meilleur $(P<0.05)$ pour les porcs sevrés nourris avec un régime à $20 \%$ $(2,47)$ que ceux nourris avec 0,10, 30 et 40\% qui avaient des valeurs de 2,57;2,49;2.48 et 2.54) en conséquence. Le ratio d'efficacité des protéines (PER) était meilleur sur $20 \%(2,38)$ par rapport à $30 \%(2,37), 10 \%(2,36)$, tandis que $0 \%$ et $40 \%(2,32)$ avaient des valeurs similaires. Les porcs nourris avec un ingrédient de test de niveau de $40 \%$ étaient meilleurs économiquement que d'autres groupes de traitement. Compte tenu du meilleur retour sur investissement, une combinaison de farine de manioc / PKC à 40\% est recommandée.

Mots clés : Porcs sevrés, écorces de manioc / galette de 'palm kernel', performance et rentabilité

\section{Introduction}

Pig has been a veritable source of animal protein in Nigeria. However, the industry is threatened by the recent pandemic COVID19 , coupled with already existing problems of inadequate supply of conventional energy source and crisis associated with herdsmen, banditry and kidnappings that has resulted in economic downturn in pig industry at national and local levels. This has aggravated the existing food insecurity and limits people ability to access nutritious food.It has been recognized over the years that the development of swine, poultry and rabbit sector in animal industry is the fastest means of bridging the protein deficiency gap prevalent in most tropical countries (FAO, 2012). This is due to their short generation interval and high fecundity
(John et al., 2014; Nkwengulila, 2014). However, Maize which constitutes the bulk of the energy source remains insufficient in supply, high price and competition with the human food and biofuel industries means there is a continuous demand for alternative energy sources for pigs and poultry Chauynarong et al. (2009). Nowadays research is focused on utilization of agricultural by-products which are less expensive and readily available. Cassava is a major staple food in the developing world, providing a basic diet for over 800 million people (Lebot, 2009; Ecocrop 2011). Nigeria alone contributed $36 \%$ of all African production of cassava, which is approximately 52 million tonne (FAOStat, 2013). Increased cassava production has opened door of opportunities to intensify 
the utilization of cassava peels in animal feeding. Cassava peels represent $5-15 \%$ of tuber weight; obtained after water-cleaning and peeling (Dierenfeld and Fagbenro, 2014). Cassava peels, leaves and tender stems are under-utilized in Nigeria because they are often left to rot away on farms and homesteads after harvesting the roots (Akinfala and Tewe, 2004). The utilization of cassava is, however, limited by a number of factors, including its high fibre and low energy content and the presence of antinutritional factors (Morgan and Choct, 2016). However, to ensure efficient use of cassava peels in pig feeding, some form of physical treatment is indispensable to the breaking down of the fibre, encapsulating the more soluble constituents so that digestive secretions can penetrate more completely (Kidder and Manner, 1978; Adrio and Demain, 2014). Several studies have been conducted on utilization of cassava peels on pigs. However, there is informationgap on the effects of combining Cassava peels and Palm Kernel cake on the performance and cost benefits of weaner pigs. The aim of this study is to evaluate the effects feeding combination of Cassava peels and palm kernel cake on performance and determine the economic benefits derived by combination with Cassava peel and PKCas alternative energy sources for the production of weaner pig.

\section{Experimental site}

The research was carried out at the piggery unit of the teaching and research farm, Faculty of Agriculture, Ambrose Alli University, Ekpoma. The farm is located in Esan West Local Government Area Council of Edo State, Nigeria; with an annual rainfall of $1500-2000 \mathrm{~mm}$ per annual. Relative humidity is $75 \%$ and average temperature is $32^{\circ}{ }_{\mathrm{C}}$

\section{Experimental animals and design}

A total of 50 weaner pigs of large white breed were used for the study. The pigs were divided into five groups with 10 pigs eachandreplicated five times with two pigs per replicate. Each group of weaner pigs were allocated to five treatment diets in a completely randomized design (CRD). Pigs were fed twice daily and water supplied adlibitum throughout the trial which lasted for ten weeks.

\section{Preparation of test ingredients}

Test ingredients Cassava peels and palm kernel cake were sourced from smallscale processors in Ekpoma. The Cassava peels were washed and sun dried for ten (10) days to reduce the moisture content to about $10 \%$. The peels were then crushed using a hammer mill to obtain cassava peel meal.

\section{Experimental diets}

The experimental diets were formulated to meet the nutrient requirements of weaner pig. The test ingredients, Cassava peels/Palm kernel cake were included at 0 , $10,20,30$ and $40 \%$ levels as a replacement of maize in the diets. The ratio of Cassava peels and Palm kernel cake were 1:1. This was done by weighing equal quantities $(\mathrm{kg})$ of the two test ingredients using a manual scale. All the diets were formulated to be iso-nitrogenous and iso-caloric (Table 1).

\section{Data collection}

Data on feed intake and weight gain were collected in the study, a known quantity of feed was provided and the corresponding left over recovered and quantified. The difference between what was given and the left over divided by the time interval is the daily feed intake. Pigs from each group were weighed at the beginning and thereafter weekly to determine the body weight. The difference between the initial and final body weight is the weight gain. Feed conversion ratio is the ratio of feed intake to the gain in weight. Protein efficiency ratio (PER) is the ratio of weight gain to the protein consumed.

\section{Economics of production}

The price of the feed ingredients at the time of the experiment was used to estimate the 


\section{Influence of graded levels of cassava peels and palm kernel cake meal on performance of weaner pigs}

cost of the production namely; Cost of feed per kg ( $)$, cost of feed per unit weight gain ( $)$, total cost of production including, cost of pigs ( $)$, feed, labour, housing, medication.Total revenue: revenue per pig (\#). Gross margin: Total cost of production per pig minus total revenue per pig.

\section{Statistical analysis}

The data collected were analyzed using SAS (2003) package, and differences between treatments means were separated using Duncan's New multiple range test as outlined by Obi (2002).

Table 1: Composition of experimental diet weaner pigs

\begin{tabular}{llllll}
\hline & \multicolumn{5}{c}{ Levels of inclusion (\%) } \\
\cline { 2 - 6 } Ingredients & $\mathbf{0 \%}$ & $\mathbf{1 0 \%}$ & $\mathbf{2 0 \%}$ & $\mathbf{3 0 \%}$ & $\mathbf{4 0 \%}$ \\
\hline Maize & 40.00 & 36.00 & 32.00 & 28.00 & 24.00 \\
Cassava peels/PKC & - & 04.00 & 08.00 & 12.00 & 16.00 \\
Ground Nut Cake & 15.87 & 17.00 & 18.13 & 19.26 & 20.39 \\
Wheat Offal & 38.18 & 36.05 & 34.72 & 33.39 & 32.06 \\
Bone Meal & 1.50 & 1.50 & 1.50 & 1.50 & 1.50 \\
Limestone & 2.00 & 2.00 & 2.00 & 2.00 & 2.00 \\
Palm Oil & 1.00 & 2.00 & 2.20 & 2.40 & 2.60 \\
Salt & 0.35 & 0.35 & 0.35 & 0.35 & 0.35 \\
Ronozyme & 0.45 & 0.45 & 0.45 & 0.45 & 0.45 \\
Lysine & 0.65 & 0.65 & 0.65 & 0.65 & 0.65 \\
Total & $\mathbf{1 0 0 . 0 0}$ & $\mathbf{1 0 0 . 0 0}$ & $\mathbf{1 0 0 . 0 0}$ & $\mathbf{1 0 0 . 0 0}$ & $\mathbf{1 0 0 . 0 0}$ \\
Calculated Analysis: & & & & \\
Crude Protein (\%) & 18.92 & 18.54 & 18.36 & 18.69 & 18.87 \\
ME(Kcal/Kg) & 2770.86 & 2774.00 & 2734.92 & 2758.48 & 2737.44 \\
Fat (\%) & 4.58 & 6.20 & 7.80 & 9.44 & 11.09 \\
Fibre (\%) & 5.03 & 6.66 & 8.28 & 9.98 & 11.51 \\
Ash (\%) & 5.91 & 9.01 & 12.11 & 15.3 & 18.53 \\
Calcium (\%) & 0.80 & 0.80 & 0.80 & 0.80 & 0.80 \\
Starch (\%) & 41.00 & 37.79 & 34.58 & 31.34 & 28.08 \\
\hline
\end{tabular}

*Animix pig probiotic per kg diet: Vitamin A-8,000 IU,VitaminsD3-3,000 IU, Vitamins E-8 IU, Vitamin K -2mg, Vitamin B1- $1 \mathrm{mg}$, Vitamin B2-0.2 mg, Vitamin B12-5 mg, Nicotinamide-10mg, Selenium- $0.1 \mathrm{mg}$, Ca Pan tothenate- $5 \mathrm{mg}$, Fo licacid-0.5 mg, Cho line Ch loride $-150 \mathrm{mg}$,Iron-20 mg,Manganese- $80 \mathrm{mg}$, Copper $-8 \mathrm{mg}$,Zinc-50 mg, Coba 1t-0.225mg,Iodine-2 mgdetoxizyme-125g, super liv $-125 \mathrm{~g}$, prebiotic/probiotic $-655 \mathrm{~g}$, herbo methionine $-125 \mathrm{~g}$, limestone carrier $187.5 \mathrm{~g}$. Key:$\mathrm{CPM}=$ Cassava peels meal, $\mathrm{PKC}=$ Palmkernelcake, $\mathrm{GNC}=$ Groundnutcake, C.P. $=\mathrm{C}$ rude protein, $\mathrm{ME}$ $=$ Metabolizable energy

\section{Results}

Performance characteristics of weaner pigs fed experimental dietsare shown in Table 2. Initial weight of the weaner pigs ranged from 9.80 to $10.20 \mathrm{~kg}$. Results on average final weight gain of the weaner pigs fed test diets were significantly $(\mathrm{P}<0.05)$ affected. Pigs fed control diet ( $0 \%$ inclusion level of the test ingredients had the highest value, followed by $10,20,30$ and $40 \%$ with corresponding values of 24.20, 23.25, $22.60,22.20$ and $21.90 \mathrm{~kg}$ respectively. Similar trend was observed for average total weight gain with pigs fed on control diets recording the highest $(\mathrm{P}<0.05)$ value while the lowest value of $(12.00 \mathrm{~kg})$ was recorded for pigs fed on $40 \%$ inclusion level of the test ingredients. The average weekly weight gain values of $2.00,1.92,1.77,1.72$ and $1.71 \mathrm{~kg}$ and recorded for pigs fed on 0 , $10,20,30$, and $40 \%$ levels of the test ingredients differed significantly $(\mathrm{P}<0.05)$. Average feed intake values of pigs fed on control $(0 \%)$ and $10 \%$ levels of inclusion were statistically the same but, differ significantly $(\mathrm{P}<0.05)$ from other dietary treatment groups. Feed conversion ratio values of $2.53,2.49,2.47,2.48$ and 2.54 
were recorded for weaner pigs fed 0,10,20, 30 and $40 \%$ inclusion levels. However, pigs fed control $(0 \%)$ and $(40 \%)$ testdiets were statistically thesame. Protein efficiency ratio were significantly $(\mathrm{P}<0.05)$ influenced by the experimental diets, highest value was recorded in $20 \%$ (2.38) diet, followed by $30 \%$ (2.37), 10\% (2.36), while $0 \%(2.32)$ and $40 \%(2.32)$ are similar. Economics and efficiency of experimental diets presented in Table 3, indicated that feed cost $(\mathrm{N} / \mathrm{kg})$ was highest in control diet, followed by 10, 20, 30 and $40 \%$ levels of inclusion with corresponding values of N123.94, N121.92, N117.41, N113.31 and
N109.21 respectively. Total cost of feed per pig values were N4402.35, N4084.32, N3597.44, N2299.30 and N3319.98 for diets $0,10,20,30,40 \%$ respectively. Revenue per total live weight gain per pig (N) ranged from N7000 in control diet toN6000 in $40 \%$ inclusion of the test diet. The highest revenue was recorded in pigs fed with $40 \%$ inclusion of the test ingredients. Gross profit per pig $(\mathrm{N})$ showed that weaner pigs fed $40 \%$ inclusion level yielded the highest revenue. Profit values gradually decreased from pigs fed $40 \%$ level of test ingredients in the diet (N2680.02) to control diet 0\% (N2597.65) per pig.

Table 2: Performance characteristics of weaner pigs fed experimental diets

\begin{tabular}{lllllll}
\hline Parameters & \multicolumn{7}{c}{ Levels of Inclusion (\%) } & & & \\
\cline { 2 - 6 } & $\mathbf{0 \%}$ & $\mathbf{1 0} \%$ & $\mathbf{2 0} \%$ & $\mathbf{3 0} \%$ & $\mathbf{4 0} \%$ & SEM \\
\hline Average initial weight $(\mathrm{kg})$ & 10.20 & 9.80 & 10.20 & 10.10 & 9.90 & - \\
Average final weight(kg) & $24.20^{\mathrm{a}}$ & $23.25^{\mathrm{b}}$ & $22.60^{\mathrm{c}}$ & $22.20^{\mathrm{d}}$ & $21.90^{\mathrm{e}}$ & 0.11 \\
Average total weight gain $(\mathrm{kg})$ & $14.00^{\mathrm{a}}$ & $13.45^{\mathrm{b}}$ & $12.40^{\mathrm{c}}$ & $12.10^{\mathrm{d}}$ & $12.00^{\mathrm{d}}$ & 0.12 \\
Average weekly weight gain $(\mathrm{kg})$ & $2.00^{\mathrm{a}}$ & $1.92^{\mathrm{a}}$ & $1.77^{\mathrm{b}}$ & $1.72^{\mathrm{b}}$ & $1.71^{\mathrm{b}}$ & 0.07 \\
Average feed intake(kg) & $35.52^{\mathrm{a}}$ & $33.50^{\mathrm{a}}$ & $30.64^{\mathrm{b}}$ & $30.00^{\mathrm{b}}$ & $30.40^{\mathrm{b}}$ & 1.07 \\
Feed conversion ratio & $2.53^{\mathrm{a}}$ & $2.49^{\mathrm{b}}$ & $2.47^{\mathrm{b}}$ & $2.48^{\mathrm{b}}$ & $2.54^{\mathrm{a}}$ & 0.01 \\
Protein efficiency ratio & $2.32^{\mathrm{c}}$ & $2.36^{\mathrm{b}}$ & $2.38^{\mathrm{a}}$ & $2.37^{\mathrm{a}}$ & $2.32^{\mathrm{c}}$ & 0.01 \\
Mortality & - & - & - & - & - & \\
\hline
\end{tabular}

a,b,c,d,e means along the same row with different superscripts are significantly $(\mathrm{P}<0.05)$ different from each other, SEM: Standard error of mean.

Table 3: Economics and efficiency of weaner pigs fed experimental diets

\begin{tabular}{llllll}
\hline & \multicolumn{5}{c}{ Levels of Inclusion (\%) } \\
\cline { 2 - 6 } Parameters & $\mathbf{0}$ & $\mathbf{1 0}$ & $\mathbf{2 0}$ & $\mathbf{3 0}$ & $\mathbf{4 0}$ \\
\hline Average initial weight/pig(kg) & 10.20 & 9.80 & 10.20 & 10.10 & 9.90 \\
Average final weight gain/pig(kg) & 24.20 & 23.25 & 22.60 & 22.20 & 21.90 \\
Average total weight gain/pig(kg) & 14.00 & 13.45 & 12.40 & 12.10 & 12.00 \\
Feed cost (A/kg) & 123.94 & 121.92 & 117.41 & 113.31 & 109.21 \\
Total feed consumed/pig(kg) & 35.52 & 33.50 & 30.64 & 30.00 & 30.40 \\
Total cost of feed consumed/pig (N) & 4402.35 & 4084.32 & 3597.44 & 3399.30 & 3319.98 \\
live weight gain & & & & & 6000 \\
Revenue/total live weight gain/pig (\#) & 7000 & 6725 & 6200 & 6050 & 600 \\
Gross profit/pig (\#) & 2597.65 & 2640.68 & 2602.56 & 2650.70 & 2680.02 \\
\hline
\end{tabular}

\section{Discussion}

The effect of feeding graded level of Cassava peels/PKC meal on body weight, feed intake, feed conversion ratio and protein efficiency ratio is presented in Table 2. Significant differences $(\mathrm{P}<0.05)$ were observed among treatment groups for average final weight, average total weight gain, average weekly weight gain, feed conversion ratio, protein efficiency ratio and average feed intake. This is in agreement with findings of Torhemen et al. (2018) who in similar study reported significant $(\mathrm{P}<0.05)$ difference in live body weight, weight gain, feed intake and feed conversion ratio of weaner pigs fed enzyme 
treated Cassava peel meal. However, the result of average weekly weight gain and average feed intake values for weaner pigs fed on $0 \%$ and $10 \%$ test diets are not statistically different $(\mathrm{P}>0.05)$. Weaner pigs fed 20,30 and $40 \%$ test ingredient sshad similar values and did not differ statistically from each other. Average total weight gain recorded in this study decreased with increased levels of the test ingredients. The observed decreased performance of weaner pigs fed Cassava/Palm kernel cake based diets in this study may be attributed to the inability of the weaner pigs to digest the high fibre diets. Studies conducted by Fakolade (1977); Arowora et al. (1999) reported the occurrence of high amounts of non-starch polysaccharides (NSP) in cassava peels. Hence, the degradation of these carbohydrate compounds to simple sugars will further increase the energy value of cassava peels, while the need for the addition of exogenous enzymes (ronozyme) enhanced theutilization of the cassava peels diet for monogastric animals (Moseri, 2019).Feed conversion ratio was better in cassava peels based diets compared to control which may be attributed to ronozyme inclusion in the feed that enhanced the digestion, this is in line with report of Adesehinwa et al. (2011) who observed better feed conversion ratio in a similar study with pigs. Feed cost per $\mathrm{kg}$ was lowest in diet 5 (109.21) and highest ( 123.94) in control diet. Similarly, total cost of feed consumed per pig was lowest ( $\$ 3319.98)$ in $40 \%$ and highest ( $¥ 4402.35$ ) in the control diet; this may be attributed to high cost of maize. Similar studies conducted by Balogun, (1980); Adesehinwa, et al. (2011) reported that cassava peels can be introduced up to $30 \%$ in piglet diets without affecting growth rate while cost of feed per $\mathrm{kg}$ live weight gain observed in $40 \%$ diet translated to more revenue and profit in the experimental diets. Thus, $40 \%$ inclusion level of the test ingredients provedmore cost effective compared to other treatments. Similarly, weaner pigs fed on 10, 20 and $30 \%$ inclusion levels were more profitable than the control diet $(0 \%)$.

\section{Conclusion}

The study showed that pigs fed on $40 \%$ level test ingredient had highest return on investment and therefore recommended.

\section{References}

Adesehinwa, A. O. K., Obi, O. O., Makanjuola, B. A., Oluwole, $\mathrm{O}$. O. and Adesina, M. A. 2011. Growing Pigs Fed Cassava Peel Based Dietsupplemented With or Without Farmazyme 3000 Proenx: Effect on Growth, Carcass and Blood. African Journal Biotechnology, 10 (14): 27912796.

Adrio, J. L and Demain, A. L. (2014). Microbial enzymes: Tools for biotechnological processes. Biomolecules 4(1):117-139.

Akinfala, E. O. and Tewe, O. O. 2004. Supplemental effects of feed additives on the utilization of whole cassava plant by growing pigs in the tropics. Livestock Research for Rural Development 16(10).

Arowora, K.A., Tewe, O. O., Fasein, T. O. and Lamina, D. R. O. 1999. Carbohydrate Constituents of cassava peel Clones and their utilization in Pig Grower Rations. Tropical Animal Production Investment 2: 29-34

Balogun, D. O. and Fetuga, B. L. 1980. Liver glutamate oxaloacetic transaminase activity in pigs as influenced by dietary methionine and lysine. Biotechnology 16: 4350.

Bogart, R. and Taylor, R. E. (1983). 
Scientific farm Animal production. $2^{\text {nd }}$ edition, MacMillian Publishing Company, New York, USA

Chauynarong, N., Elangovan, A. V. and Iji P. A. 2009. The potential of cassava products in diets for poultry World's Poultry Science Journal. DOI:

https://doi.org/10.1017/S0043933 $\underline{909000026}$

Dierenfeld, E. S. and Fagbenro O. A. 2014. Use of cassava in livestock and aquaculture feeding programs. ILRI Discussion Paper 25. Nairobi, Kenya: International Livestock Research Institute.

Ecocrop, 2011. Ecocrop database. FAO, Rome.

FAO, 2012. Food and Agriculture Organization of the United Nations. The state of food insecurity in the World, Rome.

FAOStat, 2013. Food and Agriculture Organization of the United Nations

Fakolade, A. T. 1997. Effect of Polysaccharide Supplementation on the Performance of Layers maintained on $45 \%$ Corn Offal and $40 \%$ Wheat Offal Diets. $B$. Sc. Dissertation, University of Ibadan, Ibadan, Pp. 84.

John, S. W., Harder, J. M., Fingert, J. H. and Anderson, M. G. 2014. Animal models of exfoliation syndrome, now and future. Journal Glaucoma 23: 68-72.

Kidder, D. E. and Manners, M. J. 1978. Digestibility. In: Digestion in the pig. Bath, England: Kington Press. pp. 190-197

Lebot, V. 2009. Tropical root and tuber crops: cassava, sweet potato, yams and aroids. Crop Production Science inHorticulture (17), CAB books. Wallingford, UK: CABI

Medel, P. Garcia, M., Lazaro, R., Deblas,
C. and Mateoa, G.G. 2000. Particle size and heat treatment of barley in diets for early-weaned piglets. AnimalFeed and Science Technology 84; 12-21.

Morgan, N. K, Choct, M. 2016. Cassava: Nutrient composition and nutritive value in poultry diets, Review $\begin{array}{llllll}A & n & i & m & a & l\end{array}$ Nutrition,http://dx.doi.org/10.101 6/j.

Moseri, H., Oboh, S. O. and Okosun, S. E. 2019. Effect of Feeding Cassava Peels Meal and Palm Kernel Cake (PKC) Mixture on the Productive Performance of Grower Pigs. NigerianJournal of Animal Science and Technology, 1(3): 110.

Nkwengulila, G. 2014. The Financial Costs Associated with Porcine Cysticercosis and Epilepsy in Iringa Rural District. Health 6(21):2959.

Obi, I. U. 2002. Statistical Methods of Detecting Differences Between Treatment Means and Research Methodology Issues in Laboratory and Field experiments, AP Express Publishing Company, Limited, 1319.

Oboh, O. S., Igene, F. U and Christopher, A. C. 2010. Effects of Cooking Time on the Nutritive Values of A f r i c a $\mathrm{n}$ Y a m b e a $\mathrm{n}$ (SphenostylisStenocoarpa). The Coconut: a Multidisciplinary Journal of Environment, Agriculture and Technology. National Association for Research and Development, University of Calabar, Nigeria. 1(1).

Oboh S. O, Moseri, H. and Okosun, S. E. 2018. Assessment of Cassava Peels and Palm Kernel Cake (PKC) on the Performance of Grower Pigs.International Journal of 
Influence of graded levels of cassava peels and palm kernel cake meal on performance of weaner pigs

Research in Agriculture and Forestry Volume 5, Issue 10, 2018, PP 1-5

Statistix, 2003. Statistics for windows manual. Copyright 1985-2003. Analytical software. Version 8.0

Tewe, O. O. 2004. The global cassava development strategy: cassava for livestock feed in Sub-Saharan Africa. IFAD and FAO.
Torhemen, L. N., Ikurior, S. A., Wuanor

A. A., Torhemen, M. 2018. Effect of Enzyme Treated Cassava Peel Meal Based Diets on Growth Performance and Nutrient Digestibility of Weaner Pigs. International Journal of Environment, Agriculture and Biotechnology (IJEAB). Vol-3, I s s u e - 1, http://dx.doi.org/10.22161/ijeab/3 .1.

Received: $30^{\text {th }}$ August, 2020 Accepted: $21^{\text {st }}$ November, 2020 